\title{
Feasibility Study on the Use of Vegetable Oil (Natural Ester) in Malaysia Power System Transformers
}

\author{
Abubakar A. Suleiman and Nor Asiah Binti Muhamad ${ }^{\dagger}$ \\ UTM Skudai Institute of High Voltage and High Current (IVAT), Faculty of Electrical Engineering, University Teknologi \\ Malaysia, UTM Skudai, Johor, Malaysia
}

Received June 12, 2012; Accepted February 19, 2014

\begin{abstract}
Power transformer insulation oil is critical to the useful life of the transformer. Although mineral base insulation oil is the most common type of transformer insulation oil in use, environmental and safety concerns has encouraged the development of biodegradable alternatives. Today, Envirotemp ${ }^{\circledR}$ FR3 ${ }^{\mathrm{TM}}$ is in commercial use and this study is aimed at ascertaining the possibility of applying the oil in Malaysia power transformers. A sample of Envirotemp ${ }^{\circledR}$ FR3 ${ }^{\mathrm{TM}}$ was tested to measure and compare the technical (including electrical, chemical and physical) properties of the oil according to Malaysian standards. The study found that the oil sample had better qualities, such as higher dielectric strength, lower dissipation factor, higher flash and fire points, higher moisture absorption capability, and less dissolved gases composition amongst others. However, it was also ascertained that further development in this area could be hindered due to Malaysia's lack of standards for biodegradable oil.
\end{abstract}

Keywords: Insulation oil, Biodegradable oil, Envirotemp ${ }^{\circledR}$ FR3 ${ }^{\mathrm{TM}}$, Mineral oil, Power transformer

\section{INTRODUCTION}

The importance of transformers in the power system cannot be overemphasized. The power transformer is required in the power system to step up or down generation or transmission voltages for the use of commercial or residential electricity consumers in industries, shops/markets and homes. The reliability and performance of the power transformer depends upon the properties of its high voltage insulating materials, whether it is acting independently or in composite with one another. The principal insulating materials in any oil filled transformer is kraft paper or pressboards. It insulates the intra and inter turn windings, and the insulation oil acts as both the insulator and heat exchange medium [1].

Of these two, the one that is the most susceptible to contamination is the insulation oil. Hence, it is important to consider the choices of insulation oil available to use in transformers.

${ }^{\dagger}$ Author to whom all correspondence should be addressed: E-mail: norasiah@fke.utm.my

Copyright $(2014$ KIEEME. All rights reserved. This is an open-access article distributed under the terms of the Creative Commons Attribution Non-Commercial
License (http/////reatativecommmons.org/licenses//y-n/3.0) which permits unrestricted noncommercial use,
distribution, and reproduction in any medium, provided the original work is properly cited. distribution, and reproduction in any medium, provided the original work is properly cited

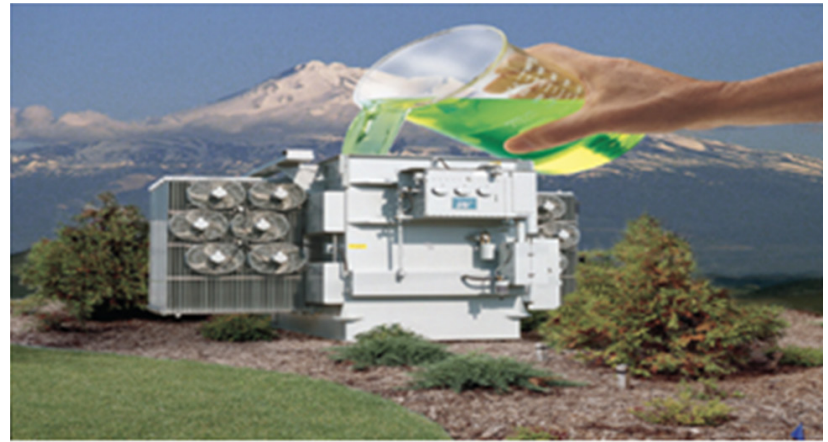

Fig. 1. Filling a transformer with environtemp FR3 [5].

Reasons such as, performance, cost and availability make petroleum based insulation fluid the most common insulation fluid for oil filled transformers [2]. As much as electrical power system engineers try to prevent it, transformer faults and accidents still occur and when they do, transformer tanks can rapture, causing large quantities of the non-biodegradable mineral oil to spill onto the ground [3]. The transformer can also explode, causing 
the highly flammable oil to ignite and burn profusely. These two reasons were primary in necessitating the extensive research to find alternative insulation oil that is biodegradable with high flash and fire points amongst other advantages. By the end of the $19^{\text {th }}$ century, vegetable oil had been successfully developed for commercial use and is currently used in many power transformers with remarkable performance. record [4].

Most of power transformers used in Malaysian power system networks are filled with petroleum-based mineral oils as insulation fluid. These transformers contain large quantities of mineral oil and can be disastrous to the environment in cases of tank ruptures or leaks [6]. The objective of this study is therefore to undertake a critical examination and ascertain the properties of a natural ester vegetable oil sample (Envirotemp ${ }^{\circledR}$ FR3 ${ }^{\mathrm{TM}}$ ), comparing it with the Malaysian Standard for oil filled transformers as well as carry out a cost benefit analysis and environmental impact assessment of using the oil in Malaysian power system transformers.

\section{METHODOLOGY}

A sample of the natural ester oil, from the manufacturer, was tested according to the SIRIM certified standard MS 2322:2010 (Fluids for electroctechnical application - Unused mineral insulating oils for transformers and switchgear) [7]. This standard is an adaptation of IEC 60296. The purpose of the test was to determine the electrical and physiochemical properties of the oil sample and then compare the result to the MS Standard and the manufacturers given property values.

The result of the test and analysis is presented in the next section.

\section{RESULTS AND FINDINGS}

\subsection{Technical Analysis}

The result of the Envirotemp® ${ }^{\circledR}$ FR3 ${ }^{\mathrm{TM}}$ natural ester oil sample tested was compared to the standard values given by MS 2322:2010 and the properties of ester given by the manufacturers of the oil [7]. The Electrical, Chemical and Physical property results of the sample of oil tested are summarized in the tables 2 to 4 below

The result shows that the Envirotemp® ${ }^{\circledR}$ FR3 ${ }^{\mathrm{TM}}$ tested based on the Malaysian Standard MS 2322:2010 has

\section{i. Higher moisture content \\ ii. Higher dissipation factor \\ iii. Higher pour point \\ iv. Higher neutralization value \\ v. Lower Inter Facial Tension (IFT)}

\subsection{Cost benefit and performance assessment}

Based on the information given on power transformers tripping that were recorded in the financial year (FY) 2008/09 and 2009/10 by TNB and the 2003 International Machinery Insurers' Association (IMIA), and a worldwide study on the analysis of transformer failures over a period of five years between 1997 to 2001 [8], it showed losses due to transformer insulation failures in Malaysia. It compares power lost using mineral oil compared to what it would have been if FR3 were used. The summary is shown in Figs. 2 and 3 below

Furthermore, the use of the natural ester, biodegradable Envirotemp ${ }^{\circledR} \mathrm{FR} 3^{\mathrm{TM}}$ insulation oil can reduce this cost because the oil.
Table 1. Electrical properties of sample vs FR3 and MS.

\begin{tabular}{ccccc}
\hline Type of test & unit & Test Result & Malaysia Std & FR3 Value \\
\hline \hline $\begin{array}{c}\text { Dielectric Break- } \\
\text { down @ } 2.5 \mathrm{~mm}\end{array}$ & $\mathrm{kV}$ & 85 & $30 \mathrm{Min}$ & $\geq 40$ \\
\hline Power Factor $(\tan \delta)$ & $\%$ & 0.01342 & $0.005 \mathrm{Max}$ & $\leq 0.20$ \\
\hline Resistivity & G $\Omega . \mathrm{m}$ & 22 & No limit at $90^{\circ} \mathrm{C}$ & $\geq 5 \mathrm{e} 12 \Omega$-cm \\
\hline
\end{tabular}

Table 2. Chemical properties of sample vs FR3 vs MS.

\begin{tabular}{|c|c|c|c|c|c|}
\hline \multicolumn{2}{|c|}{ Type of test } & unit & Test Result & $\begin{array}{c}\text { Malaysia } \\
\text { Std } \\
\end{array}$ & FR3 Value \\
\hline \multirow{15}{*}{$\begin{array}{l}\text { Dissolved } \\
\text { Gas Analy- } \\
\text { sis }\end{array}$} & $\begin{array}{c}\text { Hydrogen } \\
\left(\mathrm{H}_{2}\right)\end{array}$ & ppm & 7 & 100 & \\
\hline & $\begin{array}{c}\text { Oxygen } \\
\left(\mathrm{O}_{2}\right)\end{array}$ & ppm & 10410 & $\begin{array}{c}\text { Not } \\
\text { specified }\end{array}$ & \\
\hline & $\begin{array}{c}\text { Nitrogen } \\
\left(\mathrm{N}_{2}\right)\end{array}$ & ppm & 54792 & $\begin{array}{c}\text { Not } \\
\text { Specified }\end{array}$ & \\
\hline & $\begin{array}{c}\text { Methane } \\
\left(\mathrm{CH}_{4}\right)\end{array}$ & ppm & 1 & 120 & \\
\hline & Carbon & & & & \\
\hline & Monoxide & ppm & 8 & 350 & \\
\hline & (CO) & & & & \\
\hline & Carbon & & & & \\
\hline & $\begin{array}{c}\text { Dioxide } \\
\left(\mathrm{CO}_{2}\right)\end{array}$ & ppm & 270 & 2,500 & \\
\hline & $\begin{array}{c}\text { Ethylene } \\
\left(\mathrm{C}_{2} \mathrm{H}_{4}\right)\end{array}$ & ppm & Nil & 50 & \\
\hline & $\begin{array}{l}\text { Ethane } \\
\left(\mathrm{C}_{2} \mathrm{H}_{6}\right)\end{array}$ & ppm & Nil & 65 & \\
\hline & $\begin{array}{l}\text { Acetylene } \\
\left(\mathrm{C}_{2} \mathrm{H}_{2}\right)\end{array}$ & ppm & Nil & 35 & \\
\hline & Total & & & & \\
\hline & Dissolved & ppm & 16 & & \\
\hline & Comb Gas & & & & \\
\hline \multicolumn{2}{|c|}{$\begin{array}{l}\text { Neutralization No. } \\
\text { (Acidity) }\end{array}$} & $\mathrm{mgKOH} / \mathrm{g}$ & 0.02 & $0.01 \mathrm{Max}$ & $\leq 0.06$ \\
\hline \multicolumn{2}{|c|}{ Moisture } & ppm & 86 & 30 Max & $\leq 200$ \\
\hline \multirow{3}{*}{$\begin{array}{l}\text { Oxidation } \\
\text { Stability }\end{array}$} & Acidity & $\mathrm{mgKOH} / \mathrm{g}$ & 3.41 & 1.2 Max & \\
\hline & Sludge & $\%$ & 1.16 & $0.8 \max$ & \\
\hline & $\begin{array}{c}\text { Power Fac- } \\
\text { tor }(\tan \delta)\end{array}$ & $\%$ & & 0 & \\
\hline
\end{tabular}

Table 3. Physical properties of sample vs FR3 vs MS.

\begin{tabular}{|c|c|c|c|c|}
\hline Type of test & Unit & Test result & Malaysia Std & FR3 Value \\
\hline Color & No & L 1.0 & $1.0-2.5$ & L 0.5 \\
\hline $\begin{array}{c}\text { Interfacial } \\
\text { tension (IFT) }\end{array}$ & $\mathrm{mN} / \mathrm{m}$ & 27 & 40 Min & $25-28$ \\
\hline Density & $\mathrm{g} / \mathrm{cm}^{3}$ & 0.9195 & $<0.895$ Max & \\
\hline Flash point & ${ }^{\circ} \mathrm{C}$ & 240 & 135 Min & $\geq 340$ \\
\hline Pour Point & ${ }^{\circ} \mathrm{C}$ & -21.9 & -40 Max & $\leq-18$ \\
\hline $\begin{array}{l}\text { Kinematic } \\
\text { Viscosity }\end{array}$ & $\mathrm{mm}^{2} / \mathrm{s}$ & 32.5 & $12 \mathrm{Max}$ & $\leq 40$ \\
\hline Appearance & & $\begin{array}{c}\text { Pale yellow } \\
\text { (No contami- } \\
\text { nation) }\end{array}$ & & $\begin{array}{c}\text { Transparent, } \\
\text { Light green }\end{array}$ \\
\hline
\end{tabular}

i. Has a higher breakdown voltage; thus reducing risk of insulation breakdown at lower voltages.

ii. Has a higher flash point; thus less risk of failure due to fire [9].

iii. Has a higher viscosity and so has higher heat dissipation rate; reduced operating temperature.

iv. Absorbs moisture expelled from kraft paper; therefore reducing its degradation rate and failure due to aging [10-12] 


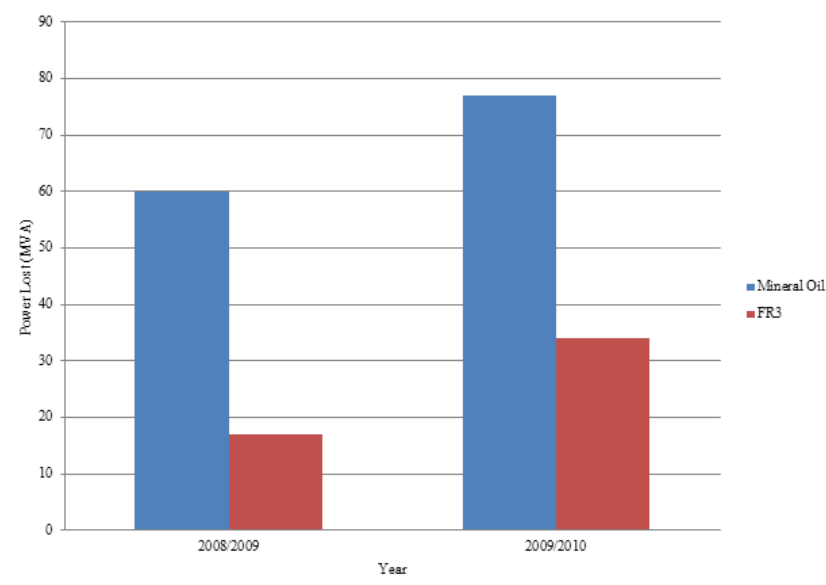

Fig. 2. Power (MVA) lost due to insulation related failure (FR3 vs. Mineral oil).

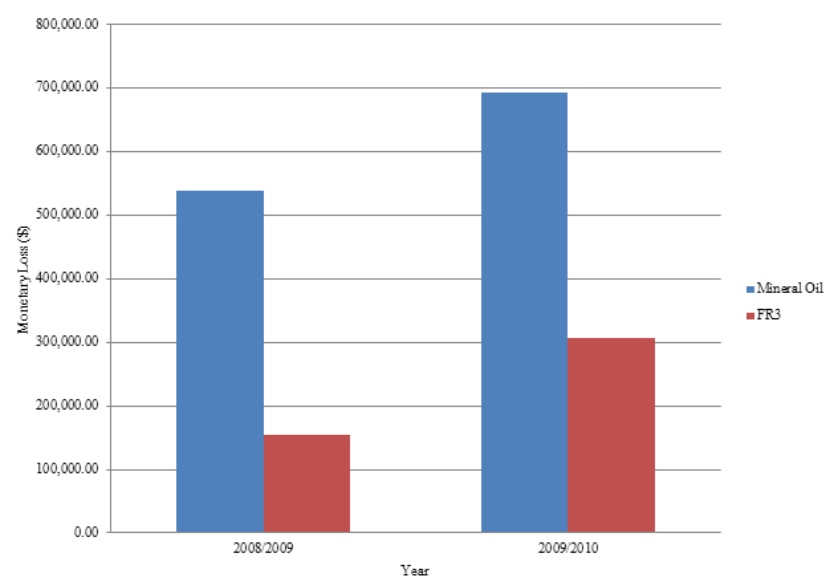

Fig. 3. Estimate equipment losses due to insulation failure.

This study has established that natural ester/vegetable insulation oil

i. Has a higher dielectric breakdown voltage than mineral oil, implying that it can withstand higher electrical stress under the same operation and environmental conditions.

ii. Has a higher susceptibility to absorb moisture from the kraft paper, which is better than mineral oil. This characteristic of ester oil is uniquely important as it reduces the rate of kraft paper degradation and so elongates the life cycle of the transformer [11-15].

iii. Is compatible with all components of the transformer because the long chain fatty acid structure of the oil makes it non-corrosive; it has negligibly low chemical reaction with the other transformer components [16].

iv. Has a high flash point, which invariably reduces the risk of transformer fires due to insulation oil burning after arcing faults inside the transformer.

v. Also has a high thermal withstand characteristic resulting from the high flash point [17].

vi. Can be cost effective in terms of maintenance, operations and performance.

vii. Is environmentally friendly and ease to dispose without fear of toxicity to the eco system

So far, the major cost disadvantage for this oil is that it is not readily available and so its initial cost is higher than that of min-

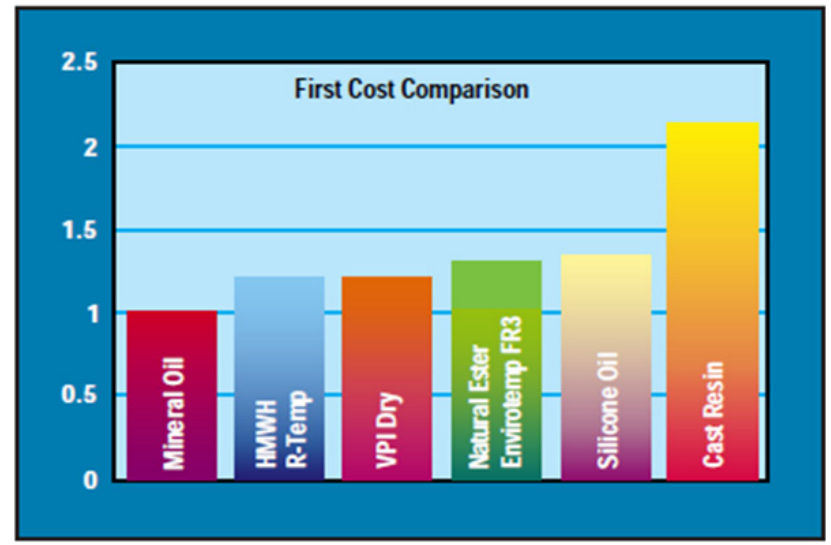

Fig. 4. Initial cost of insulation oils [18].

eral oil as shown in Fig. 4 below.

\subsection{Environmental impact assessment}

In this century, almost all engineering equipment designed without the consideration of their impact to the sustainable development of the society (protection of the eco-system) or safety of their operation can be deemed as failures. Therefore, environmental impact assessments of any new engineering design is essential for sustainable development. The impact of engineering equipment is so important that existing equipment are being redesigned to fit our fragile ecology.

Therefore, in terms of the environment, natural ester insulation oil

i. Is biodegradable and eco-friendly. It contains no toxic chemicals.

ii. It has no waste disposal issues because it is perfectly eco friendly.

iii. The source is renewable.

iv. No fire hazards when compared to mineral oils because of it high flammable level.

\section{CONCLUSIONS AND RECOMMENDATION}

The Malaysian climatic and weather conditions are unique with high humidity, frequent rain, and a lot of lighting [19]. So it is pertinent that new insulation oil proposed to be used in the power frequency transformers are tested before use. The test should compare results with existing standards and show the effect regarding the unique Malaysian weather on the biodegradable insulation oil Envirotemp ${ }^{\circledR}$ FR3 ${ }^{\mathrm{TM}}$ when used in local environmental conditions. At the end of this study, it was established that the feasibility study showed that the commercially available biodegradable insulation oil could be introduced in Malaysian power transformers either as new insulation oil or as retro-fill.

\subsection{Limitations}

The cost benefit analysis is based on postulations that arrived with reference to previous studies on transformer failures worldwide, as there was little data available from the public utility company, TNB, despite the enthusiasm of that the VP TNB Transmission had in this research. The only information available from TNB were the number of transformers in the power net- 
work in Malaysia and unsigned causes of transformer tripping recorded in the financial year (FY) 2008/09 and 2009/10.

\subsection{Recommendations}

With this conclusion reached, it is therefore recommended that further work on this project should

i. Apply the oil in a transformer and monitor its performance; retro filling will serve this purpose because the oil is compatible with the other transformer components.

ii. Seek more statistical data from TNB, in order to have a more accurate cost benefit analysis (Including claims for damages and litigations).

iii. Seek the development of Malaysian Standard for biodegradable insulation oil filled transformers.

iv. Develop palm oil to use as insulation oil to make natural ester oils readily available and cheap.

\section{ACKNOWLEDGMENTS}

This work acknowledges the desire of the Tenaga National Berhad (TNB) VP transmission and his principal managers for an environmentally safer alternative for transformer insulation oils. Author also would like to acknowledge Ministry of Education Malaysia, Ministry of Sciences aand Technology Malaysia and Universiti Teknologi Malaysia for financial support under grant number 4L607, 04H67 and 4S101

\section{REFERENCES}

[1] S. S. Rao, Power Transformers and Special Transformers. Delhi: Khanna Publishers, 2004.

[2] N. H. Malik, et al., Electrical Insulation in Power Systems. New York: Marcel Dekker, 1998.

[3] P. Information, "The Evolution of Soybean Based Transformer Oil at Waverly Light and Power," in Internet, W. L. Power, Ed., ed: Waverly Light \& Power.

[4] C. C. W. Claiborne, E.J.; Oommen, T.V., "An agriculturally based biodegradable dielectric fluid," Transmission and Distribution Conference, 1999 IEEE, vol. 2, pp. 876 - 8811999.

[5] Bulletin, "Envirotemp ${ }^{\circledR}$ FR3 ${ }^{\mathrm{TM}}$ Fluid ", I. Cooper Power Systems, Ed., ed: Cooper Industries Ltd @ http://www.nttworldwide.com/docs/fr3brochure.pdf (Accessed 15/09/10), 2005.

[6] U. U. Abdullahi, "Evaluation of Palm Oil Potential as Liquid Dielectric Fluid in High Voltage Applications," MSc, Faculty of Engineering, University Putra Malaysia, Selangor, 2004.

[7] SIRIM, "MS 2322:2010 (Fluids for Electrotechnical Applications - Unused Mineral Insulating Oils for Transformers and Switchgear)," ed. online: SIRIM \& Department of Standards Malaysia,
2010.

[8] W. H. Bartley, "Analysis of Transformer Failures," presented at the 36th Annual Conference International Association of Engineering Insurers@ http://www.bplglobal.net/eng/knowledgecenter/download.aspx?id=191 (accessed 10/10/10), Stockholm, 2003.

[9] IEEE, "Guide for Substation Fire Protection," in IEEE Std 9791994 IEEE, Ed., ed: Digital Object Identifier [DOI: http://dx.doi. org/10.1109/IEEESTD.1995.122615 1995].

[10] G. Frimpong, et al., "Measurement and Modelling of Dielectric Response of Composite Oil/Paper Insulation," Proceedings of the 5th International Conference on Properties and Applications of Dielectric Materials vol. 1, pp. 86-89, 1997 [DOI: http:// dx.doi.org/10.1109/ICPADM.1997.617534].

[11] C. P. McShane, et al., "Aging of Kraft Paper in Natural Ester Dielectric Fluid " Proceedings of 2002 IEEE 14th International Conference on Dielectric Liquids, 2002. ICDL 2002., pp. 173177, 2002.

[12] S. Tenbohlen and M. Koch, "Aging Performance and Moisture Solubility of Vegetable Oils for Power Transformers " IEEE Transactions on Power Delivery vol. 25, pp. 825-830, 2010 [DOI: http://dx.doi.org/10.1109/TPWRD.2009.2034747].

[13] V. Mentlík, et al., "Aging of petroleum and synthetic based insulation oils from the view of structural analyses " IEEE International Conference on Dielectric Liquids, pp. 1-4, 2008.

[14] N. A. Muhamad, "Condition Monitoring of Biodegradable Oil-Filled Transformers Using DGA, PD and PDC Measurement Techniques " Ph.D, School of Electrical Engineering and Telecommunications The University of New South Wales, New South Wales, 2009

[15] T. V. Oommen, "Vegetable oils for liquid-filled transformers " Electrical Insulation Magazine, IEEE vol. 18, pp. 6 - 112002 [DOI: http://dx.doi.org/10.1109/57.981322].

[16] I. L. Hosier, et al., "Ageing of biodegradable oils for high voltage insulation systems," IEEE Conference on Electrical Insulation and Dielectric Phenomena, pp. 481 - 484, 2006.

[17] L. Yang, et al., "Study on the Influence of Natural Ester on Thermal Ageing Characteristics of Oil-paper in Power Transformer " ICHVE 2008. International Conference on Digital Object Identifier: 10.1109/ICHVE.2008.4773967 pp. 437 - 440, 2008 [DOI: http://dx.doi.org/10.1109/ICHVE.2008.4773967].

[18] Bulletin, "Rethinking Transformers For Safety, Performance, and Value: Transformer Selection Guide," in Internet @ http:// www.cooperindustries.com/content/dam/public/powersystems/resources/library/210_3phTransformers/00006.pdf (Accessed 16/04/11), ed: Cooper Power Systems Inc, 2000.

[19] MMD, "General Climate of Malaysia ", M. M. D. (MMD), Ed., ed. Internet @ http://www.met.gov.my/index.php?option=com_ content\&task $=$ view\&id $=75 \&$ Itemid $=1089 \&$ limit $=1 \&$ limitstart $=0$ (Accessed 04/04/11): Ministry of Science, Technology and Innovation (MOSTI), 2010. 